\begin{tabular}{|c|c|c|c|c|}
\hline $\begin{array}{c}\text { Jurnal Penelitian \& } \\
\text { PPM }\end{array}$ & ISSN: 2442-448X & Vol 4, No: 2 & Hal: $129-389$ & Juli 2017 \\
\hline
\end{tabular}

\title{
PEMBERDAYAAN PETANI KOPI MELALUI PENGUATAN KAPASITAS DALAM PENGOLAHAN HASIL KOPI DI DESA GENTENG, KECAMATAN SUKASARI, KAB. SUMEDANG
}

\author{
OLEH : \\ NURLIANA CIPTA APSARI, ARIE S. GUTAMA, NUNUNG NURWATI, HERY WIBOWO, RISNA RESNAWATY, RUDI SAPRUDIN DARWIS, \\ MEILANNY B. SANTOSO, SAHADI HUMAEDI

\footnotetext{
1. Pusat Studi Kesejahteraan Anak dan Keluarga Fakultas Ilmu Sosial dan Ilmu Politik Universitas Padjadjaran

2. Pusat Studi Kewirausahaan Sosial, CSR dan Pengembangan Masyarakat Fakultas Ilmu Sosial dan Ilmu Politik Universitas Padjadjaran

. Pusat Studi Kewirausahaan Sosial, CSR dan Pengembangan Masyarakat Fakultas Ilmu Sosial dan Ilmu Politik Universitas Padjadjaran

4. Pusat Studi Kesejahteraan Anak dan Keluarga Fakultas Ilmu Sosial dan Ilmu Politik Universitas Padjadjaran

5. Pusat Studi Kewirausahaan Sosial, CSR dan Pengembangan Masyarakat Fakultas Ilmu Sosial dan Ilmu Politik Universitas Padjadjaran

6. Pusat Studi Kesejahteraan Anak dan Keluarga Fakultas Ilmu Sosial dan Ilmu Politik Universitas Padjadjaran

7. Pusat Studi Kewirausahaan Sosial, CSR dan Pengembangan Masyarakat Fakultas Ilmu Sosial dan Ilmu Politik Universitas Padjadjaran

8. Pusat Studi Kewirausahaan Sosial, CSR dan Pengembangan Masyarakat Fakultas Ilmu Sosial dan Ilmu Politik Universitas Padjadjaran
}

\begin{abstract}
ABSTRAK
Desa Genteng, Kecamatan Sukasari, Kabupaten Sumedang, merupakan daerah pegunungan dan perbukitan, termasuk dalam kategori dataran tinggi dengan ketinggian tempat 800-1200 mdpl. Desa Genteng, Kecamatan Sukasari, Kabupaten Sumedang, merupakan daerah pegunungan dan perbukitan, termasuk dalam kategori dataran tinggi dengan ketinggian tempat 800-1200 mdpl. Salah satu potensi yang dimiliki oleh Desa Genteng adalah pada sektor perkebunan yaitu kebun kopi, yang telah menjadi menjadi roda perekonomian dalam menopang kehidupan bermasyarakat. Berdasarkan hasil assessment lapangan mengenai kondisi masyarakat akan ketersediaan kegiatan pelestarian lingkungan hidup, maka dapat ditinjau bahwa masyarakat belum memiliki kesadaran akan pentingnya pelestarian lingkungan hidup atas dasar hasil dari kegiatan perekonomian masyarakat sehingga memungkinkan terjadinya kesinambungan antara kegiatan perekonomian masyarakat dengan pelestarian lingkungan hidup.

Dalam hal ini, maka potensi untuk pengendalian stabilitas lingkungan hidup dapat ditelaah dari keadaan mayoritas mata pencaharian warga yang didominasi oleh Petani Kopi. Mitra tidak mampu memasarkan secara maksimal hasil kopi, salah satu kendala yang dirasakan oleh mitra adalah kemasan produk yang kurang memadai. Selain itu mitra juga berikeinginan untuk dapat mengolah biji kopi menjadi kopi yang siap saji dengan kualitas yang bagus. Maka dapat ditinjau bahwa perlu diadakannya program Pengabdian Kepada Masyarakat melalui kegiatan Pelatihan Pemberdayaan Petani Kopi Melalui Penguatan Kapasitas Dalam Pengolahan Hasil Kopi di Desa Genteng, Kecamatan Sukasari, Kabupaten Sumedang.
\end{abstract}

Kata Kunci : Kopi, Pemberdayaan Petani, Pengabdian Masyarakat

\section{ABSTRACT}

Tile Village, District Sukasari, Sumedang district, a mountainous and hilly areas, included in the category of the highlands with altitude 800-1200 meters above sea level. Tile Village, District Sukasari, Sumedang district, a mountainous and hilly areas, included in the category of the highlands with altitude 800-1200 meters above sea level. One of the potential possessed by the Village tiles are in the plantation sector is coffee plantations, which have become into the economy in sustaining society. Based on the results of a field assessment of the condition of the people would be the availability of environmental conservation activities, it can be evaluated 
that the people had no awareness of the importance of environmental conservation on the basis of the results of public economic activities so as to enable the continuity between public economic activities with environmental conservation.

In this case, the potential for environmental stability control can be explored from the state of the majority of the livelihood of citizens who are dominated by the Coffee Growers. Partners are not able to market to the maximum yield coffee, one of the obstacles perceived by the partner is inadequate packaging products. In addition it also berikeinginan partners to be able to process the coffee beans into the coffee is ready to eat with good quality. Then it can be viewed that need to be holding Community Services program through training activities Coffee Farmers Empowerment Through Processing Capacity Building In Coffee in the Village tiles, District Sukasari, Sumedang regency.

Keywords $\quad$ : Coffee, Farmers Empowerment, Community Devocation

\section{PENDAHULUAN}

\section{Latar Belakang}

Desa Genteng, Kecamatan Sukasari, Kabupaten Sumedang, merupakan daerah pegunungan dan perbukitan, termasuk dalam kategori dataran tinggi dengan ketinggian tempat 800-1200 mdpl. Desa Genteng, Kecamatan Sukasari, Kabupaten Sumedang, merupakan daerah pegunungan dan perbukitan, termasuk dalam kategori dataran tinggi dengan ketinggian tempat 800-1200 mdpl. Salah satu potensi yang dimiliki oleh Desa Genteng adalah pada sektor perkebunan yaitu kebun kopi, yang telah menjadi menjadi roda perekonomian dalam menopang kehidupan bermasyarakat. Aktivitas perkebunan dan pengolahan kopi sudah ada sejak tanggal 10 Desember 2009 hingga sekarang, yang dikoordinasikan oleh Koperasi Berdikari. Koperasi Berdikari telah menanam kurang lebih 14.700 bibit kopi arabica Variates Kartika I. Penanaman dilakukan diatas ketinggian $1200 \mathrm{mdpl}$, di kaki gunung Cijambu Desa Genteng Kecamatan Sukasari Kabupaten Sumedang.

Aktivitas penanaman serta pengolahan kopi ini merupakan salah satu penopang pengahasilan warga terutama warga di Dusun I Desa Genteng, dan berdasarkan hasil assement awal diperoleh informasi bahwa selain memiliki potensi, terdapat juga beberapa masalah yang dihadapi oleh para petani kopi antara lain : belum memiliki sarana proses produksi pasca panen, alat/mesin untuk proses produksi masih kurang, kelompok belum memiliki modal yang cukup, dan anggota kelompok/kelompok kesulitan memasarkan langsung produk kopinya. Dengan memperhatikan kondisi tersebut, maka tim PKM berkesimpulan bahwa perlu adanya sebuah kegiatan yang mampu memberikan dampak postif terhadap peningkatan pemasaran atau produktifitas kopi dengan mengadakan sebuah kegiatan Pelatihan Mengenai Olahan Kopi dan Pengemasan Produk Kopi bagi para petani/kelompok tani kebun kopi Desa Genteng.

Kegiatan PPM ini berjudul Pemberdayaan Petani Kopi Melalui Penguatan Kapasitas Dalam Pengolahan Hasil Kopi di Desa Genteng, Kec. Sukasari, Sumedang yang ditujukan bagi para petani/kelompok tani kebun kopi Desa Genteng. Adapun tujuan dari kegiatan PPM adalah meningkatkan kemapuan para petani kopi untuk dapat megolah hasil kebun kopi secara maksimal, sebab masalah yang selama ini dirasakan oleh para petani adalah minimnya pemasaran hasil kopi yang disebabkan oleh rendahnya pengetahuan dan keterampilan petani dalam mengolah biji kopi siap saji.

\section{Kelompok Sasaran}

Kelompok sasaran dari kegiatan PPM ini adalah masyarakat petani kopi di Desa Genteng. Kegiatan PKM ini akan dilaksanakan di Desa Genteng tepatnya di Dusun I, pemilihan lokasi tersebut didasarkan pada terdapatnya potensi yang dapat dkembangkan seperti potensi kopi jenis arabica Variates Kartika I yang menjadi salah satu penopang sumber penghidupan masyarakat di Dusun I Desa Genteng. Sementara itu kelompok sasaran dari kegiatan PKM ini adalah yaitu para petani yang memiliki usaha dalam pengolahan kopi. 


\section{Perumusan Masalah}

Desa Genteng memiliki kekayaan sumber daya manusia dan alam yang melimpah.Desa Genteng merupakan salah satu desa dengan jumlah penduduk terbesar di Kecamatan Sukasari dengan kekayaan sumber daya alam berupa kopi dan tembakau yang menjadi komoditas bagi mata pencaharian petani kopi dan tembakau. Namun, jumlah penduduk yang besar dengan aktivitas dan mobilitas petani kopi yang tinggi dalam pengelolaan tanaman kopi dan tembakau memberikan dampak terhadap kelestarian lingkungan hidup di sekitarnya. Adapun tujuan dari kegiatan PPM adalah meningkatkan kemapuan para petani kopi untuk dapat mengolah hasil kebun kopi secara maksimal, sebab masalah yang selama ini dirasakan oleh para petani adalah minimnya pemasaran hasil kopi yang disebabkan oleh rendahnya pengetahuan dan keterampilan petani dalam mengolah biji kopi siap saji.

\section{Tujuan dan Manfaat}

\section{Tujuan}

Tujuan dari kegiatan Pengabdian kepada Masyarakat ini adalah :

4. Meningkatkan kapasitas petani kopi desa Genteng dalam pengelolaan hasil alam, yaitu kopi

5. Masyarakat diharapkan dapat lebih produktif untuk mengelolahasil pertanian kopi.

\section{Manfaat}

Manfaat dari kegiatan Pengabdian kepada Masyarakat ini adalah:

1. Petani kopi di Desa Genteng dapat mengetahui dan memahami tentang pengolahan kopi dan pengemasan yang memadai.

2. Petani kopi di Desa Genteng mampu dalam pengolahan kopi secara memadai dan pembuatan pengemasan yang kreatif.

3. Kelompok sasaran dapat lebih termotivasi untuk mengembangkan budidaya kopi.

\section{MATERI DAN METODE}

\section{Khalayak Sasaran}

Masyarakat Desa Genteng ditinjau tepat untuk menjadi penerima dari pelatihan dalam program pengabdian pada masyarakat ini. Desa Genteng merupakan salah satu dari 7 Desa di Wilayah Kecamatan Sukasari Kabupaten Sumedang yang terletak $3 \mathrm{Km}$ ke arah Utara dari Kecamatan Sukasari. Program Pengabdian pada Masyarakat (PPM) Prioritas ini tepat ditujukan kepada masyarakat Desa Genteng perihal keterkaitan dengan kondisi dan kebutuhan masyarakat Desa Genteng dan sesuai dengan salah satu misi Desa Genteng berdasarkan RPJM Desa Genteng 2016 tentang Peningkatan usaha ekonomi masyarakat.

\section{Hasil Assessment dan Observasi Lapangan}

Desa Genteng memiliki potensi sumber daya alam dan manusia yang melimpah. Hal ini ditinjau dari ketersediaan dan potensi lahan serta potensi Desa Genteng sebagai salah satu desa dengan jumlah penduduk terbesar di Kecamatan Sukasari, Kabupaten Sumedang sehingga berdampak pada percepatan pembangunan desa bila dioptimalkan dengan tepat. Namun, pembangunan desa belum terlaksana secara optimal oleh karena beberapa hambatan yang disebabkan oleh keinginan masyarakat untuk bertahan pada pola aktivitas keseharian secara tradisional.

Berdasarkan RPJM Desa Genteng (2016), mayoritas Desa Genteng berpendidikan Sekolah Dasar (SD) dengan jumlah 921 orang. Hal ini menjadi sebuah perhatian bagi pemangku kepentingan pemerintahan desa yang mengkhawatirkan masa depan perekonomian, sosial, dan budaya masyarakat yang masih berpaku pada pekerjaan turun temurun sebagai petani selepas lulus sekolah dasar dengan anggapan bahwa pendidikan bukan hal yang menjadi penting. Hal ini bukan hanya berdampak pada mayoritas pekerjaan dan jumlah pengangguran pada masyarakat desa, namun juga berpengaruh terhadap pola pemikiran masyarakat desa terhadap pengelolaan potensi dan penanganan masalah yang terdapat pada sumber daya alam dan manusia di lingkungan fisik dan sosial di sekitarnya. Aktivitas penanaman serta pengolahan kopi ini merupakan salah satupenopang pengahasilan warga terutama warga di Dusun I Desa Genteng, dan berdasarkan hasil assement awal diperoleh informasi bahwa selain memiliki potensi, terdapat juga beberapa masalah yang dihadapi oleh para petani kopi antara lain: belum memiliki sarana proses produksi pasca panen, alat/mesin untuk proses produksi masih kurang, kelompok belum memiliki modal yang cukup, dananggota kelompok/kelompok 
kesulitan memasarkan langsung produk kopinya. Dengan memperhatikan kondisi tersebut, maka tim PKM berkesimpulan bahwa perlu adanya sebuah kegiatan yang mampu memberikan dampak postif terhadap peningkatan pemasaran atau produktifitas kopi dengan mengadakan sebuah kegiatan Pelatihan Mengenai Olahan Kopi dan Pengemasan Produk Kopi bagi para petani/kelompok tani kebun kopi Desa Genteng.

\section{Analisa Kebutuhan Berdasarkan Hasil Assessment Lapangan}

Berdasarkan hasil assessment lapangan mengenai kondisi masyarakat akan ketersediaan kegiatan pelestarian lingkungan hidup, maka dapat ditinjau bahwa masyarakat belum memiliki kesadaran akan pentingnya pelestarian lingkungan hidup atas dasar hasil dari kegiatan perekonomian masyarakat sehingga memungkinkan terjadinya kesinambungan antara kegiatan perekonomian masyarakat dengan pelestarian lingkungan hidup. Dalam hal ini, maka potensi untuk pengendalian stabilitas lingkungan hidup dapat ditelaah dari keadaan mayoritas mata pencaharian warga yang didominasi oleh Petani Kopi. Mitra tidak mampu memasarkan secara maksimal hasil kopi, salah satu kendala yang dirasakan oleh mitra adalah kemasan produk yang kurang memadai. Selain itu mitra juga berikeinginan untuk dapat mengolah biji kopimenjadi kopi yang siap saji dengan kualitas yang bagus.

Berdasarkan penelaahan hasil assessment lapangan, maka dapat ditinjau bahwa perlu diadakannya program pengabdian kepada masyarakat melalui kegiatan pelatihan Pemberdayaan Petani Kopi Melalui Penguatan Kapasitas Dalam Pengolahan Hasil Kopi di Desa Genteng, Kecamatan Sukasari, Kabupaten Sumedang.

\section{Metode Pelaksanaan PKM}

Metode yang digunakan dalam kegiatan PPM adalah dengan melakukan kegiatan pelatihan yang diawali terlebih dahulu dengan pemberian materi, kemudian diskusi, dan praktik atau simulasi. Kegiatan pelatihan dipandu oleh narasumber (tenaga ahli) sebagai fasilitator pelatihan dan dibantu dengan seperangkat alat untuk melakukan simulasi atau praktik secara langsung. Adapun tahapan dalam kegiatan PKM diantaranya adalah persiapan kegiatan PPM, Pemetaan Wilayah,
Pelaksanaan Pelatihan, dan Monitoring dan Evaluasi.

\section{Indikator Keberhasilan Kegiatan}

Setiap kegiatan tentunya harus memiliki tujuan dan manfaat, demikian juga dalam kegiatan PPM ini memiliki tujuan dan manfaat yang perlu untuk diwujudkan melalui tahapan dan proses yang sistematis dan terukur. Adapun indikator - indikator keberhasilan kegiatan dalam PPM ini diantaranya adalah Mitra mengetahui dan memahami tetang pengolahan kopi dan pengemasan yang memadai, Mitra mampu dalam pengolahan kopi secara memadai dan pengemasan secara kreatif, Kelompok sasaran telah termotivasi untuk mengembangkan budidaya kopi, Tim berhasil menulis artikel dan dipublikasikan pada jurnal, yaitu Jurnal Share.

\section{HASIL DAN PEMBAHASAN}

\section{Kegiatan Assessment}

Berdasarkan penelaahan data sekunder desa dan observasi lapangan, maka diketahui bahwa sebagian besar lahan di Desa Genteng digunakan untuk lahan pemukiman dan pertanian. Mayoritas penduduk menggunakan lahan pertanian untuk penanaman kopi dan tembakau.Dalam hal transportasi, maka mayoritas masyarakat Desa Genteng menggunakan transportasi publik seperti halnya Angkutan Umum dan Ojeg. Salah satu angkutan umum akan melewati Desa Genteng menuju pasar tradisional di Tanjungsari. Hal ini memudahkan bagi masyarakat desa untuk menempuh perjalanan bila tidak ada kendaraan pribadi. Masyarakat juga seringkali menggunakan motor bila jarak tempuh jauh dan memerlukan waktu yang cepat. Dalam hal ini, kondisi jalan raya di Desa Genteng masih berbatu dan terbilang rawan untuk kendaraan karena kondisi jalan yang curam dan banyak jalan berlubang.Jalan sekitar pemukiman masih belum beraspal dan masih berlandaskan tanah.

Berdasarkan informasi yang diperoleh dari mayoritas warga yang bekerja sebagai petani kopi, maka diketahui bahwa rata-rata penghasilan petani kopi tidak lebih dari Rp 2.500.000/bulan.Hal ini didasarkan atas dasar penghasilan rata-rata petani kopi bila hasil panen maksimal yaitu Rp 21.000.000 per tahun.Adapun pola pemukiman warga dibagi atas dasar pemetaan batas wilayah dusun dan memanjang di sepanjang jalan.

Dalam hal pendidikan, masyarakat Desa Genteng rata-rata berpendidikan SD (Sekolah 
Dasar) dengan jumlah 921 orang.Namun, hal ini terbilang berkembang setelah dibukanya SMP Terbuka bagi masyarakat dengan pendidikan akhir SD. Sarana prasarana pendukung pendidikan di Desa Genteng belum memadai. Kondisi infrastruktur pendukung ketersediaan pelayanan pendidikan masih perlu diperbaharui. Ketersediaan sekolah sudah memberikan aksesibilitas yang mudah bagi masyarakat untuk menempuh pendidikan di desa. Namun, jarak tempuh yang jauh seringkali memberikan beban kepada anggota masyarakat dengan perekonomian rendah untuk menyekolahkan anaknya. Hal ini juga didukung oleh tradisi pola pemikiran masyarakat yang masih menganggap bahwa pendidikan hanya cukup sampai sekolah dasar, setelah itu anak dapat meneruskan usaha orangtuanya untuk menjadi petani karena dinilai penghasilan petani sudah mencukupi kebutuhan keluarga.Dalam hal ini, penduduk laki-laki lebih banyak yang memiliki pendidikan lebih tinggi dibandingkan dengan penduduk perempuan.Pola pemikiran masyarakat yang masih terfokus pada penerusan usaha orangtua untuk bertani sehingga kesadaran untuk bersekolah hingga jenjang yang lebih tinggi masih belum mumpuni. Kesadaran akan pentingnya pendidikan bagi perkembangan pertanian warga juga belum tersosialisasikan dengan baik.

Dalam hal kelembagaan, beberapa anggota masyarakat sudah berinisiasi untuk mendirikan koperasi.Namun, koperasi ini belum berjalan dan warga lebih memilih untuk meminjam uang kepada pendonor swasta dibandingkan dengan ketersediaan koperasi.Kelompok tani kopi, kelompok tani tembakau, kelompok pengrajin bambu tersedia di Desa Genteng.Masing-masing kelompok memiliki perwakilan di setiap dusun dan belum terfokus pada persatuan untuk pembangunan sosial ekonomi anggotanya.Komunitas pengrajin bambu telah menghasilkan produk industri rumah tangga dari bambu.Namun hal ini belum mendukung perkembangan masyarakat untuk mengarah kepada industry kreatif.Adapun petani tembakau belum memiliki pengelolaan hasil produk, sedangkan petani kopi sedang merintis pengelolaan produk hasil kopi untuk dipasarkan dalam bentuk jadi.

Interaksi sosial masyarakat terlihat sangat baik bila ditinjau dari masih adanya sifat kegotongroyongan masyarakat dalam berbagai kegiatan.Misalnya saja dalam kegiatan kerja bakti sosial, kegiatan pembangunan baik yang dilaksanakan oleh perorangan ataupun kegiatan yang berkaitan dengan program pemerintah. Baik yang dilaksanakan oleh pemerintah desa ataupun kegiatan-kegiatan yang dilaksanakan melalui program lainnya. Seperti halnya gotong-royong dalam kegiatan pembangunan desa atas kerjasama dengan pemerintah desa, kebersihan lingkungan, membangun sarana umum dan sarana keagamaan, membantu warga yang tertimpa musibah (kematian), kawinan, membuat hunian, dII)

Pola tanam bagi petani kopi dan tembakau didasarkan atas perhitungan musim yang tepat. Petani kopi dalam hal ini diuntungkan karena letak desa dengan ketinggian yang sudah memadai bagi produk kopi berkualitas dan dukungan pemerintah atas ketersediaan pemanfaatan hutan semi lindung. Namun, pola tanam masih menggunakan alat-alat tradisional oleh karena kebiasaan masyarakat dan ketidakinginan untuk berubah terhadap pemanfaatan teknologi. Tiap dusun memiliki kelompok tani tersendiri yang ditujukan untuk mempererat hubungan antar petani dan bekerjasama dalam pengelolaan hasilnyan. Namun, hingga saat ini, kelompok tani yang paling aktif bekerjasama dan berkoordinasi adalah kelompok tani kopi. Nilai produksi kopi per tahun bagi petani kopi yang belum mengelola produk kopinya menjadi hasil jadi ialah Rp 21.000.000 dengan estimasi jumlah kopi seberat 3 Ton. Adapun Nilai jual hasil panen kopi per kg adalah Rp $7.000,00$. Namun, bila tengkulak sudah mengolah hasil kopi tersebut untuk kemudian diproduksi menjadi kopi siap minum, maka nilai jualnya akan bertambah menjadi sekitar Rp 23.000/kg di pasar tradisional.

Desa Genteng memiliki potensi yang cukup besar, baik dari sumber daya manusia maupun sumber daya alam.Salah satu potensi dalam sumber daya alam yang terdapat di Desa Genteng adalah ketersediaan kopi dan tembakau. Namun, berdasarkan data RPJM Desa Genteng (2016), sampai saat ini potensi sumber daya belum benarbenar optimal diberdayakan. Beberapa hambatan yang dihadapi oleh masyarakat dalam pengelolaan sumber daya alam diantaranya adalah masih kurangnya penanam saham potensial yang berkenan untuk menanamkan modal investasinya di Desa Genteng serta masyarakat belum memiliki pengetahuan dan kecakapan khusus dalam pengelolaan sampah sisa pengolahan sumber daya alam sehingga berakibat pada pencemaran tanah, air, dan udara di Desa Genteng.

Program Pengabdian Kepada Masyarakat (PKM) Prioritas ini tepat ditujukan kepada masyarakat Desa Genteng perihal keterkaitan 
dengan kondisi dan kebutuhan masyarakat Desa Genteng dan sesuai dengan Misi ke-5 Desa Genteng berdasarkan RPJM Desa Genteng 2016 tentang "Pelestarian Lingkungan Hidup". Dalam misi tersebut disebutkan bahwa terwujudnya pelestarian lingkungan hidup yang dapat berhasil guna dapat melalui penataan lingkungan baik yang terbentuk secara alamiah atau hasil penataan masyarakat.

\section{Kegiatan Pelatihan}

Tahapan berikutnya adalah kegiatan pelatihan, kegiatan pelatihan ini berjudul: Pemberdayaan Petani Kopi Melalui Penguatan Kapasitas Dalam Pengolahan Hasil Kopi di Desa Genteng, Kecamatan Sukasari, Kabupaten Sumedang. Pelatihan ini bertujuan untuk : Meningkatkan kapasitas petani kopi dalam mengelola hasil alam, pengolahan kopi pasca panen untuk menghasilkan produk yang berkualitas.

Kegiatan pelatihan ini menguraikan materi meliputi pengolahan kopi pasca panen yang standard sehingga menghasilkan kopi yang berkualitas oleh merupakan mitra kerja dari Kopi Malabar yang memiliki memiliki usaha perkebunan kopi sekaligus ketua kelompok petani kopi di Rancakalong, Sumedang.

Pelatihan ini akan menggunakan metode pendidikan orang dewasa dengan prinsip belajar dari pengalaman. Prinsip inilah yang menjadi landasan pendekatan seluruh proses pelatihan dimana peserta menjadi pelaku utama dalam pencapaian tujuan pelatihan.

Peserta berpartisipasi aktif dalam kegiatan dengan menjalani setiap tahapan kegiatan dengan baik dan antusias ditinjau dari banyaknya peserta yang terlibat dalam kegiatan praktik dan tanya jawab, Materi yang diberikan dalam kegiatan ini sudah sesuai dengan TOR kegiatan yang diajukan kepada pemateri. Sebelumnya, penyusunan TOR sendiri disesuaikan dengan hasil assessment yang dilakukan untuk mengetahui apa materi yang dibutuhkan oleh petani kopi di desa Genteng. Respon yang diberikan oleh peserta juga cukup bagus, terlihat dari cukup aktifnya peserta dalam tanya jawab dengan pemateri.

Berdasarkan hasil pre-test dan post-test, maka dapat ditinjau bahwa peserta mengalami perubahan yang positif dengan meningkatkan pengetahuan akanpengolahan kopi pasca panen untuk mendapatkan nilai-nilai ekonomis dari pengelolaannya.

\section{Rencana Keberlanjutan Program}

Merujuk pada hasil-hasil kegiatan PPM yang telah dilakukan, terutama kegiatan pelatihan mengenai pelatihan Pemberdayaan Petani Kopi Melalui Penguatan Kapasitas Dalam Pengolahan Hasil Kopi, maka nampakya diperlukan kegiatan pendampingan bagi keberlanjutan pengelolaan hasil kopi, baik itu pra maupun pasca panen. Pendampingan dilakukan guna meningkatkan kreativitas petani kopi dalam mengelola hasil alam yaitu kopi hingga memiliki daya jual dan nilai ekonomis yang cukup tinggi, dari hasil kopi yang berkualitas.Kegiatan ini dapat dijalankan dengan kegiatan penguatan kelompok usaha yang diadakan atas dasar pelatihan koperasi desa, guna terjalinnya kerjasama kelembagaan pemerintah dengan masyarakat setempat.

\section{KESIMPULAN DAN SARAN}

\section{Kesimpulan}

Berdasarkan pemetaan dan assesment yang dilakukan mengenai kondisi masyarakat dan potensi sumberdaya yang ada. Dalam hal ini, maka potensi untuk pengendalian stabilitas lingkungan hidup dapat ditelaah dari keadaan mayoritas mata pencaharian warga yang didominasi oleh Petani Kopi. Sebelumnya, mitra tidak mampu memasarkan secara maksimal hasil kopi, salah satu kendala yang dirasakan oleh mitra adalah kemasan produk yang kurang memadai. Selain itu mitra juga berikeinginan untuk dapat mengolah biji kopimenjadi kopi yang siap saji dengan kualitas yang bagus. Aktivitas penanaman serta pengolahan kopi ini merupakan salah satupenopang pengahasilan warga terutama warga di Dusun I Desa Genteng, dan berdasarkan hasil assement awal diperoleh informasi bahwa selain memiliki potensi, terdapat juga beberapa masalah yang dihadapi oleh para petani kopi antara lain : belum memiliki sarana proses produksi pasca panen, alat/mesin untuk proses produksi masih kurang, kelompok belum memiliki modal yang cukup, dananggota kelompok/kelompok kesulitan memasarkan langsung produk kopinya. Dengan memperhatikan kondisi tersebut, maka tim PKM berkesimpulan bahwa perlu adanya sebuah kegiatan yang mampu memberikan dampak postif terhadap peningkatan pemasaran atau produktifitas kopi dengan mengadakan sebuah 


\begin{tabular}{|c|c|c|c|c|}
\hline $\begin{array}{c}\text { Jurnal Penelitian \& } \\
\text { PPM }\end{array}$ & ISSN: 2442-448X & Vol 4, No: 2 & Hal: $129-389$ & Juli 2017 \\
\hline
\end{tabular}

kegiatan Pelatihan Mengenai Olahan Kopi dan Pengemasan Produk Kopi bagi para petani/kelompok tani kebun kopi Desa Genteng.

\section{Saran}

Pemberdayaan dan penguatan kelembagaan petani merupakan proses perubahan pola pikir dengan mempersiapkan SDM petani menjadi profesional, baik dalam teknis budidaya (produksi), dalam penanganan panen, pasca panen, pemasaran dan pengelolaan organisasi.

Dalam kegiatan ini, ada 3 faktor yang menjadi indikator bahwa kegiatan ini memiliki dampak terhadap sasaran pelatihan, yaitu keterampilan, pengetahuan, dan motivasi. Ketiga faktor ini dikuasi petani melalui proses tahapan pemberdayaan yang menggunakan sistem, strategi dan metodeyang sesuai dengan spesifik total. Untuk itu, upaya pendampingan diharapkan menjadi salah satu langkah keberlanjutan program, kegiatan pelatihan mengenai pelatihan Pemberdayaan Petani Kopi Melalui Penguatan Kapasitas Dalam Pengolahan Hasil Kopi, maka nampakya diperlukan kegiatan pendampingan bagi keberlanjutan pengelolaan hasil kopi, baik itu pra maupun pasca panen. Pendampingan dilakukan guna meningkatkan kreativitas petani kopi dalam mengelola hasil alam yaitu kopi hingga memiliki daya jual dan nilai ekonomis yang cukup tinggi, dari hasil kopi yang berkualitas. Kegiatan ini dapat dijalankan dengan kegiatan penguatan kelompok usaha yang diadakan atas dasar pelatihan koperasi desa, guna terjalinnya kerjasama kelembagaan pemerintah dengan masyarakat setempat.

\section{DAFTAR PUSTAKA}

Adi. Isbandi Rukminto. 2008. Intervensi Komunitas Pengembangan Masyarakat Sebagai Upaya Pemberdayaan Masyarakat. Jakarta: Rajawali Pers

Cary, Lee. 1970. Community Development As A Process. Missouri. Univerity of Missouri Press.

Hikmat, Harry. 2006. Strategi Pemberdayaan Masyarakat. Bandung: Humaniora Utama Press.

Ife, Jim. 2008. Community Development: Alternatif Pengembangan Masyarakat di Era Globalisasi. Jogjakarta. Pustaka Pelajar.

Kartasasmita, Ginandjar. 1996. Pembangunan untuk rakyat: memadukan pertumbuhan dan pemerataan. Jakarta. CIDES

Lewis, Judith A., 1991, Management of Human Services Programs. California Brooks/Cole Publishing Company

Parsons, Ruth J., James D. Jorgensen, Santos H. Hernandez, 1994. The Integration of Social Work Practice. Wadsworth, Inc., California

Raharjo, ST. 2015. Assessment untuk Praktik Pekerjaan Sosial dan Kesejahteraan Sosial. Bandung: Unpad Press 2015. Dasar Pengetahuan Pekerjaan Sosial. Bandung: Unpad Press. 2015. Keterampilan Pekerjaan Sosial: Dasar-dasar. Bandung, Unpad Press.

Rappaport, J., 1984. Studies in Empowerment: Introduction to the Issue, Prevention In Human Issue. USA.

Rencana Pembangunan Jangka Menengah Desa 2011-2015. Desa Genteng, Kecamatan Sukasari, Kabupaten Sumedang. 2011.

Suharto. Edi.1997.Pembangunan, Kebijakan Sosial, dan Pekerjaan Sosial. Bandung: LSP-STKS

Wibhawa.Budhi, dkk, 2010.Dasar-Dasar Pekerjaan Sosial. Widya Padjadjaran: Bandung 